\title{
CISTINE் FIBROZE்
}

\author{
Martynas Judickas, Emilija Jonaitytė, Dainius Misevičius \\ Lietuvos sveikatos moksly universiteto Medicinos fakultetas
}

Raktažodžiai: cistinè fibrozè, cistinės fibrozès diagnostika, cistinès fibrozès gydymas.

\begin{abstract}
Santrauka
Cistinė fibrozė yra pavojingas gyvybei monogeninis sutrikimas, charakterizuojamas kaip lètinis kvejpavimo takų ir virškinamojo trakto pažeidimas. Cistinè fibrozė dažniausiai pasireiškia naujagimiams. Daugejja duomenų, ịrodančių organizmo pokyčiu pradžią gimdoje. Progresuojantis plaučiu pažeidimas yra daugumos sergančiujų mirties priežastis. Pasiektas didelis proveržis, aiškinantis cistinès fibrozès patogenezę molekuliniame lygmenyje, tačiau dar nepakankamai suvokiamos priežastys, sukeliančios kvėpavimo ir kitų sistemų pažeidimus. Tyrimo tikslas - gauti naujos informacijos apie cistinès fibrozès aktualumą, sergančiųjų sunkumus ir gydymo perspektyvas. Atlikta sisteminè mokslinès literatūros apžvalga. Peržiūrèta daugiau kaip 150 publikacijų, analizei atrinktos 33 publikacijos, paskelbtos ne vèliau nei prieš 10 metu ir išanalizuotas jų turinys. Straipsnyje pateikiama šiuolaikinių mokslo žinių apie cistinę fibrozę ir jos kilmę, ligai būdingą kliniką, diagnostikos galimybes bei sunkumus, šiuo metu prieinamą gydymą ir ateities perspektyvas. Tyrimo rezultatai atskleide, kad nauji cistinès fibrozès gydymo pasiekimai igalino pristabdyti ligos progresavimą ir padidino pacientu išgyvenamumą iki 40 metų, tad toliau tobulinamos esamos bei ieškoma naujų terapinių šios retos ligos pirminès prevencijos priemonių ir gydymo galimybių.
\end{abstract}

\section{Ivadas}

Cistinè fibrozè (toliau - CF) yra autosominiu recesyviniu (toliau - AR) būdu paveldima liga, kuria dažniausiai serga Kaukazo gyventojai [1]. Europoje ši liga diagnozuojama 1 iš 2000-3000 tūkstančių naujagimių, JAV - 1 iš 3500 naujagimių [2]. Iš viso pasaulyje CF serga apie 80000 žmonių [3]. Lietuvoje CF serga apie 100 vaikų. Liga pažeidžia daugelị organų sistemų. Pirmiausia atsiranda kvėpavimo takų (toliau - KT), virškinimo sistemos, reprodukcinès sistemos, kasos ir prakaito liaukų pažeidimai [4]. Kai kuriose pasaulio šalyse, pvz., Australijoje, Jungtinejje Karalystèje, Ispanijoje ir Vokietijoje, ankstyvoji CF diagnostika užtikrinama atliekant visuotinį naujagimių tikrinimą [5,6]. Lietuvoje šis metodas dar nèra taikomas. Patobulejęs gydymas specialiuose gydymo centruose, efektyvus antibiotikų vartojimas laipsniškai ir pastoviai prailgino sergančiųjų CF gyvenimo trukmę [7]. Šiuo metu išgyvenamumas siekia apie 40 metu [1]. Naujesnių, saugesnių ir dar efektyvesnių vaistų, orientuotų ị ligos priežastị, o ne i pasekmes, paieškos tęsiasi. Individualus gydymas, paremtas paciento klinika ir specifiniu genotipu, yra tyrimų ir naujų vaistų kūrimo ateities pagrindas.

Tyrimo tikslas - gauti naujos informacijos apie cistinės fibrozės aktualumą, sergančiųų sunkumus ir gydymo perspektyvas.

\section{Tyrimo medžiaga ir metodai}

ELiteratūros paieška atlikta mokslinèse elektroninèse PubMed, ScienceDirect, UpToDate ir kitose duomenų bazėse. Duomenų analizei naudoti visateksčiai straipsniai, kurių pavadinimas, santrauka ar raktažodžiai atitiko sisteminès apžvalgos tikslą. Analizuotos publikacijos anglų kalba, pasirodžiusios ne vèliau nei prieš 10 metų. Peržiūrèta daugiau kaip 150, analizei atrinktos ir išanalizuotos 33 publikacijos. Straipsnyje pateikiami apibendrinti sisteminès jų turinio analizès rezultatai.

\section{Rezultatai ir jų aptarimas}

Cistinès fibrozès patogenezè. CF diagnozè nustatoma, kai randamas genetiškai ir (arba) funkciškai sutrikęs CF transmembraninị laidumą reguliuojantis baltymas (CFTR) [8]. CFTR baltymą koduojantis genas randamas 7 chromosomos ilgajame petyje [4]. Šiuo metu žinoma apie 2000 ịvairių mutacijų, galinčių sukelti CFTR geno mutaciją [8]. Apie 70 proc. visų randamų mutacijų sudaro fenilalanino delecija (Phe508de) [1,3]. CFTR yra membraninis baltymas epitelio ląstelèse, reguliuojantis chloro ir natrio jonų pernešimą i apikalinę membraną $[3,4,8]$. CFTR jonų kanalas randamas KT epitelio ląstelèse, seilių liaukose, kasoje, kepenyse, prakaito liaukose ir reprodukcinès sistemos epitelyje [1]. 
Dèl CFTR baltymo mutacijų gaminamas didelio klampumo sekretas plaučiuose ir kituose organuose [1]. Plaučiuose tai sukelia bronchų obstrukciją ir lètini uždegimą. Dèl didelio oksidantų ir proteazių kiekio, pakinta plaučių struktūra. Sumažejęs mukociliarinis klirensas bronchuose ir pakitęs sekretas didina bakterijų galimybę kolonizuoti KT [3,9].

Cistinès fibrozès klinika. Ligos klinika kinta priklausomai nuo CFTR geno mutacijos ir individualių organizmo veiksnių $[8,10]$. Dažniausiai CF vaikams pasireiškia KT simptomais, mekoniniu žarnų nepraeinamumu ir amžiui neadekvačia kūno mase. Suaugusiesiems - virškinimo sistemos simptomais, 3 tipo cukriniu diabetu ir nevaisingumu [8].

KT pažeidimas yra svarbiausia sergamumo ir mirštamumo nuo CF priežastis [1]. Lètinis plaučių uždegimas ir fibrozė pasireiškia 99 proc. sergančiujų CF[10]. Sutrikusios kvėpavimo sistemos simptomai yra pirmieji CF požymiai 45 proc. kūdikių ir vaikų [8]. Nuolatinis KT uždegimas, gleivių kamščiai ir bakterinè infekcija lemia smulkiųjų bronchų obstrukcijos ir bronchektazių išsivystymą [5]. Dažniausi sergančiųjų CF skundai yra kosulys ir pagausėjęs skrepliavimas. Šių pacientų plaučių pakitimai radiologiniuose vaizduose stebimi ilgiau nei 3 mèn., o bakteriologiniai pasèliai gali būti nuolatos teigiami. Dažniausios bakterijos, kolonizuojančios KT, yra Staphylococcus aureus, Haemophilus influenzae. Ligos paūmèjimui būdingas padažnėjęs kosulys ir skrepliavimas, blogejjanti plaučių funkcija, kartais karščiavimas [10]. Kvépavimo funkcija tikrinama atliekant spirometriją. Jos metu randami plaučių obstrukcijos požymiai [8]. Geriausią prognostinę reikšmę turi forsuoto iškvejpimo tūris per 1 sekundę (toliau - FEV $)_{1}$ [11]. Ligos eigoje, tarp 10 ir 30 metu, kasmet prarandama po 2,3 proc. $\mathrm{FEV}_{1}$ numatomos reikšmés. Plaučiu funkcijos blogèjimas pradedamas jausti, kai $\mathrm{FEV}_{1}$ $<40$ procentų. Progresuojantis kvėpavimo funkcijos nepakankamumas yra 77 proc. pacientų mirties priežastis [10].

Apie 90 proc. sergančiujų CF yra kasos egzokrininès funkcijos nepakankamumas. Dažniausiai jis pastebimas pirmaisiais gyvenimo metais. Kasos funkcijos nepakankamumas pasireiškia steatorèja, lètine malabsorbcija, pilvo skausmais, riebaluose tirpiuju vitaminų nepakankamu pasisavinimu, kūno masès mažèjimu, vaikams būdingas sulètèjęs augimas $[4,9,10]$. K vitamino malabsorbcija pasireiškia koagulopatijomis, D vitamino - rachitu [4]. Kūdikiams sunkus kasos nepakankamumas sukelia hipoproteinemiją, edemas, elektrolitų disbalansą ir anemiją. Pacientams, kurių kasos funkcija pakankama, didesnè ūminio ir lètinio pankreatito rizika [4]. Kasos pažeidimas, sergant CF, reikalingas visą gyvenimą trunkančios pakaitinès fermentų terapijos. Reikalinga didelio kaloringumo, su dideliu riebalų kiekiu dieta, riebaluose tirpių vitaminų papildai [10]. Pakenkiama ir endokrininė kasos funkcija, dèl kurios išsivysto 3 tipo cukrinis diabetas.
Apie 20 proc. naujagimių pirmasis CF simptomas yra mekoninis žarnų nepraeinamumas, o paauglių ir suaugusiujų $(15 \%)$ - distalinès žarnyno obstrukcijos sindromas [4]. Visi vaikai, kuriems pasireiškia mekoninis žarnų nepraeinamumas, žarnų apsisukimo simptomai, turètų būti tikrinami dèl galimos CF [10]. Kiti simptomai, pasireiškiantys dèl virškinamojo trakto pažeidimo, yra gastroezofaginis refliuksas, sulètejęes virškinimas plonajame žarnyne, sulètejusi storujų žarnų motorika ir obstipacijos. Dėl pakitusios tulžies rūgščių sudèties, formuojasi tulžies akmenys. Prasidejus intrahepatinio tulžies latako obstrukcijai, išsivysto kepenų cirozė, portalinė hipertenzija [4]. Dažniausios CF komplikacijos yra per maža kūno masè, riebaluose tirpių vitaminų trukūmas, mekoninis žarnų nepraeinamumas, distalinis žarnų obstrukcijos sindromas, raumenų skausmai ir artralgija, vyrams nevaisingumas, moterims - sumažęjęs vaisingumas, sinusitas, 3 tipo cukrinis diabetas, lètinès kepenų ligos, sumažèjęs kaulų mineralinis tankis [11].

Cistinès fibrozès diagnostika. Daugumos pacientų CF diagnostika nesudètinga, nes aiški klinikinè ligos išraiška (lètinis kvėpavimo ar (ir) virškinimo sistemos sutrikimas), chloro koncentracija prakaite $>60 \mathrm{mmol} / \mathrm{l}$, nustatomos 2 CFTR geno mutacijos [12]. Tik mažiau nei 5 proc. sergančiujų CF, kurių didžioji dalis yra vidutinio ar riboto fenotipo, diagnostikos procesas sudètingesnis [12]. Šių pacientu prakaito tyrimo rezultatai yra tarpiniai, nustatomos mažiau nei 2 CF sukeliančios mutacijos, arba abu šie kriterijai kartu. Pastarieji pacientai turètų būti siunčiami ị specializuotuosius centrus, kuriuose yra galimybė atlikti tokius biologinius tyrimus CFTR funkcijai ịvertinti kaip nosies epitelio biologinių potencialų skirtumo išmatavimas (toliau - NPD) ar žarnyno srovés matavimo testas (toliau - ICM) [13].

Daugelyje šalių atliekamai visuotiniai naujagimių CF tyrimai. Esant teigiamiems šių tyrimų rezultatams, naujagimio CF diagnozei patvirtinti turi būti atliktas chloro koncentracijos prakaite tyrimas (chloro koncentracija $>60 \mathrm{mmol} / \mathrm{l}$ ) [14]. Visose visuotinių tyrimų programose pirmosios eilès tyrimas - imunoreaktyvaus tripsinogeno (toliau - IRT), pankreatinès pažaidos žymenų kiekio nustatymas naujagimio kraujo laše iš kulno [14]. IRT kiekis gali būti padidejęs ir dèl kitų priežasčių, tokių kaip perinatalinis stresas, kritinès būklès ar CFTR mutacijos nešiojimas, todèl naudojami ir antrosios eilès visuotinių tyrimų testai [14]. Pastarieji testai varijuoja tarp skirtingų programų ir gali būti CFTR mutacijos analizè, pankreato-asociacinio baltymo nustatymas ar pakartotinis IRT tyrimas [15]. Naujagimių tyrimas naudingiausias, jei diagnozè patvirtinama anksti, siektina iki 2 mènesių. Naujagimiai, kuriems CF buvo nustatyta ir pradèta kompleksiškai gydyti pirmaji gyvenimo mènesį, patyre mažiau komplikacijų, nei kūdikiai ar ankstyvojo amžiaus vaikai, 
pradèti gydyti tik 12-14 gyvenimo mėnesị. Naujagimiams stebètas mažesnis KT uždegimas, mažiau pakitusi plaučiu struktūra, pagerèjusi plaučiu funkcija ir augimas, retesnè Pseudomonas aeruginosa kolonizacija ir hospitalizacija [16]. Europos Sajungos cistinès fibrozès organizacijos $2017 \mathrm{~m}$. duomenimis, vidutinis pacientų amžius nustatant CF diagnozę yra 5 mènesiai [17].Vis dèlto, kai kuriems kūdikiams netgi nuo 1 iki 2 menesiu jau pasireiškia ligos simptomai [18]. Gydytojai turètų įtarti galimą CF diagnozę, jei vaikams ar suaugusiesiems kartojasi KT infekcijos, ypač kai kartu būna ir malabsorbcinių sutrikimų. Tai patys dažniausi simptomai, ypač tose šalyse, kuriose neatliekamas visuotinis naujagimių tyrimas [12]. CF simptomų sąrašas yra kur kas ilgesnis ir aprèpia druskos netekimo sindromus (dehidrataciją ir elektrolitų pusiausvyros sutrikimus), vyrų nevaisingumą dèl azospermijos ar sėklinio latako nebuvimo, virškinamojo trakto obstrukciją, kepenų ligas, pankreatitą ir kitas [11].

Patikimiausias ir plačiausiai naudojamas CF diagnostikos testas yra chloro koncentracijos prakaite nustatymas [19]. Dèl sutrikusios chloro reabsorbcijos, žmonių, sergančių CF, chloro koncentracija prakaite būna gerokai padidejjusi. CF diagnozé patvirtinama, kai $\mathrm{Cl}$ koncentracija prakaite yra $\geq$ $60 \mathrm{mmol} / 1$, o jei rezultatas $\leq 29 \mathrm{mmol} / 1-\mathrm{CF}$ mažai tikètina (1 pav.) [20]. Jeigu tyrimo rezultatai yra tarpiniai, atliekama papildoma CFTR genetinè analizè. Esant 2 CFTR geno mutacijoms ir ribinei chloro konsentracijai prakaite, CF diagnozè patvirtinama. Jei yra klinikinių požymių, bet nerandamos CFTR geno mutacijos, CF diagnozès atmesti negalima. Tai rodo, kad chloro koncentracijos prakaite tyrimas yra jautresnis, nei CFTR geno mutacijos nustatymas [21]. Jeigu genetinè analizè neapibrèžia CFTR genotipo, atliekami kiti biologiniai tyrimai CFTR baltymo funkcijai įvertinti - NPD ir ICM. Abu šie tyrimai standartizuoti ir jų naudingumas nustatant CFTR disfunkciją yra patvirtintas [22]. NPD yra in vivo testas, matuojantis transmukozini itampos potencialą, kuris sergančiujų CF yra neigiamesnis, palyginus su sveikujų. ICM testas yra ex vivo, skirtas CFTR funkcijai įvertinti. Šiam testui atlikti būtina rektalinė biopsija. Sergančiųų CF intestinaline chloridų sekrecija yra sutrikusi, o absorbcija išlikusi normali arba padidejusi. Šie skirtumai, nustatomi ICM testu, padeda lengvai atskirti sergančiuosius CF nuo sveikuju [23]. NPD ir ICM testai ypač naudingi CF diagnozei patvirtinti, kai tiriamujų prakaite chloro koncentracija yra tarpiné, identifikuotos mažiau nei 2 CFTR mutacijos ar rastos mutacijos klinikinè reikšmė yra nežinoma [24]. Tokie tyrimai itin naudingi regionuose, kuriuose F508del mutacijos paplitimas yra žemas, pvz., Brazilijoje ar Izraelyje [12]. Ankstyvas kūdikių igimtos CF diagnozavimas ir tinka-

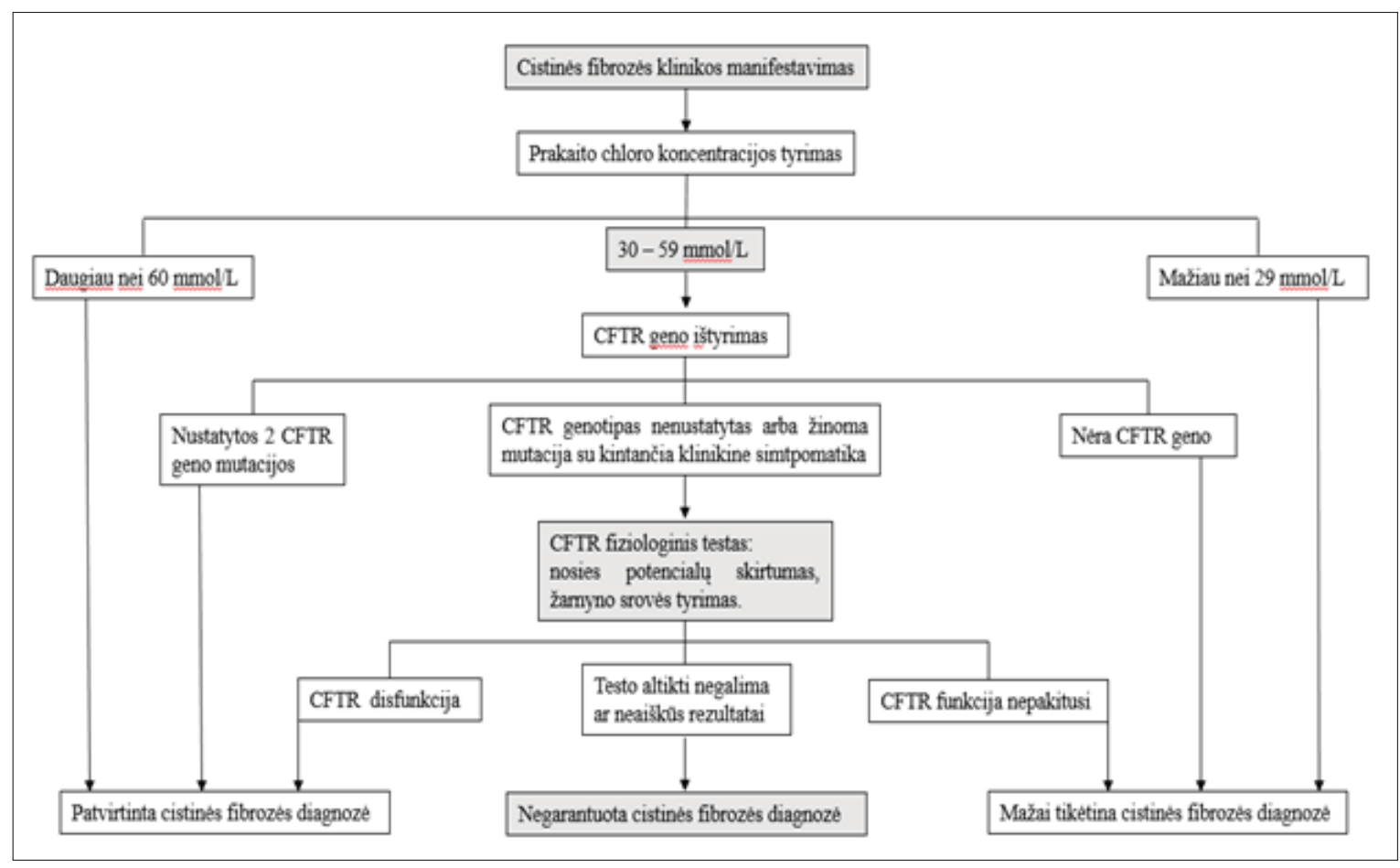

1 pav. Cistinès fibrozès diagnostikos algoritmas [20] 
mas gydymas dabartiniu laikotarpiu prailgina sergančiujų gyvenimo trukmę iki 40 metu [11].

Cistinės fibrozès gydymas ir ateities perspektyvos. CF apibrěžiama kaip reta liga, kurios paplitimas JAV yra 1 atvejis iš 200 tūkst. gyventojų. Panašus paplitimas užregistruotas ir kitose šalyse [7]. Nepaisant galimų medicininių intervencijų, sergančiųų CF gyvenimo kokybei palaikyti specifinių ir tikslinių terapijų kiekis kol kas ribotas. Naujų efektyvesnių vaistų gerinti plaučių funkciją siekiamybė yra geras vaisto toleravimas, rezistentiškumo panaikinimas ir KT infekcijų prevencija [7].

Sergančiųų CF gyvenimo trukmè per pastaruosius 40 metų pastebimai pagerèjo, tačiau dauguma pacientų miršta dèl kvẻpavimo nepakankamumo, todèl šios plaučių ligos progresavimo stabdymas yra svarbiausias CF terapijos uždavinys [10]. Visapusis plaučiu ligos valdymas kartu su greitu ir aktyviu paūmëjimų gydymu yra būtinoji sąlyga, siekiant išsaugoti kvėpavimo funkciją [25]. Pagrindinis KT pažeidimo gydymo tikslas yra gerinti mukociliarinị klirensą, taikant aktyvaus kvėpavimo terapiją, bronchų drenažo terapiją ir lètinès infekcijos gydymą antibiotikais [10]. Gydymui svarbus fizinis aktyvumas, kuris atitolina kvėpavimo funkcijos blogèjimą ir pagerina KT klirensą [11]. Tinkamas pacientų sveikatos būklès stebèjimas (1 lentelè) padeda išvengti ligos paūmèjimų.

Šiuo metu vieno vaisto nuo CF nèra. Sergančiųu gydymas orientuotas $i$ daugybinius simptomus, o ne ị ligos priežastị (klaidingą baltymų išsilankstymą) [7]. Inhaliuojamieji antibiotikai tobramicinas ir kolistinas turèjo lemiamą reikšmę mirštamumo mažinimui [26]. Sergantieji CF šiuos vaistus turi vartoti ilgą laikotarpị. Inhaliuojamieji antibiotikai mažina sisteminių šalutinių reiškinių riziką. Naujesni bei platesnio veikimo spektro antimikrobiniai vaistai būtini sergantiesiems CF, nes mikrobų rezistentiškumas yra didelė problema, siekiant sẻkmingai stabdyti plaučių ligų progresavimą [27]. Esamieji antibiotikai, tokie kaip aztreonamas

1 lentelė. Sergančiųjų cistine fibroze sveikatos būklès stebėsenos schema [11]

\begin{tabular}{|l|l|}
\hline Kartą per & 1. Matuoti pacientų ūgị ir svorị \\
$\mathbf{3}$ mėnesius & $\begin{array}{l}\text { 2. Atlikti mikrobiologinị tyrimą iš nosiaryklès, jei } \\
\text { jis teigimas - skrepliụ pasèlis } \\
\text { 3. Atlikti plaučiu funkcijos spirometriją ( }>6 \text { metų } \\
\text { vaikams) }\end{array}$ \\
\hline $\begin{array}{l}\text { Kartą per } \\
\text { metus }\end{array}$ & $\begin{array}{l}\text { 1. Ultragarsinis pilvo organų tyrimas } \\
\text { 2. Gliukozės tolerancijos testas ( }>10 \text { metų vaikams) } \\
\text { 3. Kraujo tyrimai uždegimo rodikliams ịvertinti } \\
\text { 4. Kepenų transaminazės tyrimas } \\
\text { 5. Riebaluose tirpių vitaminų kiekio kraujo serume } \\
\text { tyrimas }\end{array}$ \\
\hline
\end{tabular}

ir levofloksacinas buvo performuoti ị inhaliuojamuosius preparatus ir vèl taikomi CF plaučių ligoms gydyti [28]. Inhaliuojamieji makrolidai, tokie kaip azitromicinas, taikomi šių ligonių gydymui, pasižymi stipriu priešuždegiminiu ir antimikrobiniu veikimu [29].

Plaučių transplantacija tinkama tik labai mažam CF pacientų skaičiui. Donorinių organų trūkumas ir didelès apimties operacijos rizika yra pagrindinès šio gydymo metodo riboto taikymo priežastys [7].

Kitas alternatyvus ir daug žadantis gydymo metodas, kuriam skiriamas didelis tyrejų dėmesys, yra genų terapija. Teoriškai, ydingo geno pakeitimas sveikuoju visose paveiktose ląstelèse galètų būti taikomas kaip CF plaučių ligos gydymas [30]. Sékmingos CF genų terapijos kliūtys aprèpia heterogeninę ligos kilmę, pažeisto plaučių audinio keitimo sunkumus, tinkamo ir toleruojamo genų perkèlimo agento ar vektoriaus, užtikrinančio stabilios sveiko CFTR baltymo ekspresiją, radimą [31]. Tyrimai tęsiami, kuriuose lentivirusinis vektorius įvardijamas kaip ateityje galimas CF topikaliniai vietinių pažeidimų genų terapijos metodas [31]. Genomo taisymas sergančiujų CF kamieninèse ląstelèse intensyviai tyrinejjamas kaip potencialus gydymo metodas [32]. Daug vilčių teikia naujausi genų terapijos klinikinių tyrimų duomenys apie nebulizuotą liposominių plazmidžių DNR perkèlimą į CF paciento plaučius [33]. Tyrimo rezultatai, nors ir apibūdinti kaip vidutiniai, leidžia manyti, kad plaučių funkcija CF pacientams, gaunantiems genų terapiją, stabilizuojasi, o tikètinas $\mathrm{FEV}_{1}$ rodiklis pagereja 3,7 procento [33]. Individualiai pritaikytas bei kombinuotas terapinis gydymas, paremtas ne tik paciento klinika, bet ir genotipu - ateities tyrimų ir vaistų kūrimo tikslas.

Per pastaruosius kelerius metus pasiūlyta nemažai gydymo naujovių, ịtraukiant farmakologinę terapiją, vadinamuosius taisytojus ir suaktyvintokus, kurie gali pataisyti netikslų baltymo išsilankstymą genų terapijos vaistinius preparatus, vartojamus siekiant sureguliuoti, pataisyti, pakeisti, pridèti arba pašalinti genetinę seką, tuo pagerinant CFTR funkciją ir paveikiant CF sukeltos būklès priežastị [7]. Gydomosios intervencijos, orientuotos ị CF priežastí, yra proveržis, bet ne ligos išgydymas. Netgi turint naujus ar patobulintus CFTR modifikatorius, tikètina, ir toliau bus taikomas gydymas, orientuotas ị CF pasekmes (KT, virškinamojo trakto bei kitų sistemų sutrikimus) [7].

\section{Išvados}

Cistinès fibrozės klinika sutrikdo daugelio organų sistemų veiklą, todèl pacientams svarbus specialus kompleksinis gydymas, gerinantis gyvenimo kokybę ir išgyvenamumą. Pacientų terapija trunka visą gyvenimą, todèl svarbus jų ir artimųų supratimo apie ligą ugdymas. Kryptingas ir progre- 
suojantis gydymas per pastaraji šimtmeti padidino pacientų išgyvenamumą nuo keleto mènesių iki 40 metų. Šiandien CF diagnozė nereiškia neišvengiamos mirties, nes gydymo naujovès suteikè galimybių siekti vis ilgesnès gyvenimo trukmès ir tęsti visaverti gyvenimą, tačiau svarbu toliau tobulinti esamas bei ieškoti naujų šios retos ligos gydymo galimybių.

\section{Literatūra}

1. Harrington N, Barry PJ, Barry SM. Dental treatment for people with cystic fibrosis. Eur Arch Paediatr Dent 2016;17(3):195203.

https://doi.org/10.1007/s40368-016-0229-9

2. World health organization. Human genomics in global health. https://www.who.int/genomics/public/geneticdiseases/en/ index 2.html\#CF

3. Brown SD, White R, Tobin P. Keep them breathing: cystic fibrosis pathophysiology, diagnosis and treatment. J Am Acad Physician Assist 2017;30(5):23-7.

https://doi.org/10.1097/01.JAA.0000515540.36581.92

4. Shirodaria C, Dawkins S. Percutaneous coronary intervention chapter: percutaneous coronary intervention diagnosis and treatment in internal medicine cardiac catheterization. 2018;1-7. http://www.syntaxscore.com https://doi.org/10.1093/med/9780199568741.003.0097

5. Paranjape SM, Mogayzel PJ. Cystic fibrosis in the era of precision medicine. Paediatr Respir Rev 2018;25:64-72.

https://doi.org/10.1016/j.prrv.2017.03.001

6. Castellani C, Massie J. Newborn screening and carrier screening for cystic fibrosis: alternative or complementary. Eur Respir J 2014;43(1):20-3.

https://doi.org/10.1183/09031936.00125613

7. Fraser-Pitt D, O'Neil D. Cystic fibrosis - a multiorgan protein misfolding disease. Futur Sci O A 2015;1(2).

https://doi.org/10.4155/fso.15.57

8. Katkin JP. Cystic fibrosis: clinical manifestations and diagnosis. https://www-uptodate-com.ezproxy.dbazes.lsmuni.lt/contents/ cystic-fibrosis-clinical-manifestations-and-diagnosis

9. Sorscher EJ. Cystic fibrosis. In: Jameson JL, Fauci AS, Kasper DL, Hauser SL, Longo DL, Loscalzo J, editors. Harrison's principles of internal medicine. NY 2018. http://accessmedicine. mhmedical.com/content.aspx?aid $=1162605891$

10. Naehrig S, Chao CM, Naehrlich L. Cystic fibrosis - diagnosis and treatment. Dtsch Arztebl Int 2017;114(33-34):564-73.

https://doi.org/10.3238/arztebl.2017.0564

11. Villanueva G, Marceniuk G, Murphy MS, Walshaw M, Cosulich R. Diagnosis and management of cystic fibrosis: summary of NICE guidance. BMJ 2017;359(box 1):j4574. http://dx.doi. org/doi:10.1136/bmj.j4574

https://doi.org/10.1136/bmj.j4574

12. De Boeck K, Vermeulen F, Dupont L. The diagnosis of cystic fibrosis. Press Medicale 2017;46(6P2):e97-108.

https://doi.org/10.1016/j.lpm.2017.04.010

13. Ooi CY, Dupuis A, Ellis L, Jarvi K, Martin S, Gonska T, et al. Comparing the American and European diagnostic guidelines for cystic fibrosis: same disease, different language? Thorax 2012;67(7):618-24.

https://doi.org/10.1136/thoraxjnl-2011-201454

14. Castellani C, Massie J, Sontag M, Southern KW. Newborn screening for cystic fibrosis. Lancet Respir Med 2016;4:653-61. https://doi.org/10.1016/S2213-2600(16)00053-9

15. Sosnay PR, Farrell P. Challenges in cystic fibrosis newborn screening and recommendations for primary care physicians. Pediatrics 2015;136:1181-4.

https://doi.org/10.1542/peds.2015-3490

16. Van Devanter DR, Kahle JS, O'Sullivan AK, Sikirica S, Hodgkins PS. Cystic fibrosis in young children: a review of disease manifestation, progression and response to early treatment. J Cyst Fibros 2016;15(2):147-57. https://doi.org/10.1016/j.jcf.2015.09.008

17. Zolin A, Orenti A, Naehrlich L, van Rens J, et al. ECFSPR annual report 2017. Society 2019.

18. Zybert K, Mierzejewska E, Sands D. Clinical status and somatic development of patients with or without meconium ileus diagnosed through neonatal screening for cystic fibrosis. Dev Period Med 2015;19:41-9.

19. Domingos MT, Magdalena NI, Cat MN, Watanabe AM, RosárioFilho NA. Sweat conductivity and coulometric quantitative test in neonatal cystic fibrosis screening. J Pediatr (Rio J) 2015;91(6):590-5. https://doi.org/10.1016/j.jped.2015.03.003

20. Farrell PM, White TB, Ren CL, Hempstead SE, Accurso F, Derichs N, et al. Diagnosis of cystic fibrosis: consensus guidelines from the cystic fibrosis foundation. J Pediatr 2017;181:S4-S15. https://doi.org/10.1016/j.jpeds.2016.09.064

21. Malakauskas K, Sakalauskas R, Danila E, Zablockis R. Lietuvos suaugusiujų cistinès fibrozès diagnostikos, gydymo ir pagalbos organizavimo sutarimas. Pulmonologija, imunologija ir alergologija, 2011;1(8):2-12.

22. Tridello G, Menin L, Pintani E, Bergamini G, Assael BM, Melotti P. Nasal potential difference outcomes support diagnostic decisions in cystic fibrosis. J Cyst Fibros 2016;15:579-82. https://doi.org/10.1016/j.jcf.2016.06.009

23. De Boeck K, Kent L, Davies J, Derichs N, Amaral M, Rowe SM, et al. CFTR biomarkers: time for promotion to surrogate end-point. Eur Respir J 2013;41:203-16. https://doi.org/10.1183/09031936.00057512

24. Cohen-Cymberknoh M, Yaakov Y, Shoseyov D, Shteyer E, Schachar E, Rivlin J, et al. Evaluation of the intestinal current measurement method as a diagnostic test for cystic fibrosis. Pediatr Pulmonol 2013;48:229-35. https://doi.org/10.1002/ppul.22586 
25. Smyth AR, Bell SC, Bojcin S, Bryon M, Duff A, Flume P, et al. European cystic fibrosis society standards of care: Best practice guidelines. J Cyst Fibros 2014;13(S1):S23-42.

https://doi.org/10.1016/j.jcf.2014.03.010

26. Ryan G, Singh M, Dwan K. Inhaled antibiotics for long term therapy in cystic fibrosis. Cochrane Database Syst Rev 2011;(3):CD001021. https://doi.org/10.1002/14651858.CD001021.pub2

27. Securing new drugs for future generations: the pipeline of antibiotics. Review Antimicrobial Resistance 2015;1-42.

28. Stockmann C, Hillyard B, Ampofo K, Spigarelli MG, Sherwin CM. Levofloxacin inhalation solution for the treatment of chronic pseudomonas aeruginosa infection among patients with cystic fibrosis. Expert Rev Respir Med 2015;9(1):13-22. https://doi.org/10.1586/17476348.2015.986469

29. Siekmeier R, Hofmann T, Scheuch G. Inhalation of macrolides: a novel approach to treatment of pulmonary infections. Adv Exp Med Biol 2015; 839:13-24.

https://doi.org/10.1007/5584_2014_50

30. Lee TW, Southern KW. Topical cystic fibrosis transmembrane conductance regulator gene replacement for cystic fibrosis related lung disease. Cochrane Database Syst Rev 2013;11:CD005599. https://doi.org/10.1002/14651858.CD005599.pub4

31. Griesenbach U, Alton EW. Moving forward: cystic fibrosis gene therapy. Hum Mol Genet 2013; 22(R1):R52-R58. https://doi.org/10.1093/hmg/ddt372

32. Schwank G, Koo BK, Sassalli V, et al. Functional repair of CFTR by CRISPR/Cas9 in intestinal stem cell organoids of cystic fibrosis patients. Cell Stem Cell 2013;13(6),653-658.

https://doi.org/10.1016/j.stem.2013.11.002
33. Alton EW, Armstrong DK, Ashby D, et al. Repeated nebulisation of non-viral CFTR gene therapy in patients with cystic fibrosis: a randomised, double-blind, placebo controlled, Phase $2 \mathrm{~b}$ trial. Lancet Respir Med 2015;3(9):684-691.

https://doi.org/10.1016/S2213-2600(15)00245-3

\section{CYSTIC FIBROSIS}

\section{Judickas, E. Jonaitytė, D. Misevičius}

Keywords: cystic fibrosis, cystic fibrosis diagnostic criteria, cystic fibrosis treatment.

Summary

Cystic fibrosis (CF) is a life threatening, monogenic disorder that is characterized by a chronic lung and gastrointestinal involvement. Progressive pulmonary disease is the main cause of death in the majority of these patients. Despite a breakthrough achieved in understanding the pathogenesis of the disease in a molecular level, there still remains a large gaps in the knowledge of the origin of CF lung and other systems disease. CF can manifest in infancy, and there is growing evidence that abnormalities begins in utero. Although new advances in the treatment that allows to delay disease progression, the primary prevention should be the key target of cystic fibrosis care. In this systemic review we discuss about current knowledge of CF and its origin, clinical manifestations, diagnostic possibilities with the challenges it faces and present treatment with future perspectives. The goal of our report is to remind about the relevance of the disease, difficulties that patients with CF has and prospects of the future treatments.

Correspondence to: e.joonaityte@gmail.com

Gauta 2020-04-25 